very pleased to see the expanded section on chronic secretory otitis media which was inadequately dealt with before. The new tympanoplastic procedures which are described are the ones that have become well established. New techniques of objective audiometry are rightly included because they will certainly be one of the main fields of advance in the next few years. I was disappointed, however, not to see more about the complications of stapedectomy; particularly as Mr Mawson's own work has helped our understanding of these. He should have found room for a section on the diagnosis and management of a perilymph fistula.

The latest edition of this excellent and comprehensive book is essential reading for every E.N.T. registrar but what a pity it is that the publishers have increased the price so much. Even in these inflationary times a rise in price from $£ 5$ in 1963 to $£ 18.50$ now seems unreasonable for an established work without colour. I am afraid that as a result many postgraduate students will only see it on library shelves whereas they should own their own copies for constant reference and guidance.

\section{Medical Psychiatry Journal Articles: a Collection of Current} Articles Related to Medical Psychiatry

Edited by F. Gordon Foster and Richert E. GoyetTE. Pp. 415, illustrated, board cover. London: H. K. Lewis \& Co. Ltd for Medical Examination Publishing Co., Inc., 1974. £6.00.

The existence of such a volume as this appears to this reviewer to be a reflection of certain aspects of psychiatry in the U.S.A. today. Whilst there has, in fact, always been a firm biological basis to the subject acknowledged within many academic centres there, there has also been a powerful psychoanalytic emphasis, excellent in many ways, but which has probably been destructive of the more direct clinical descriptive phenomenological approach common in Europe. Perhaps partly as a result of this, in recent years in the U.S.A. the status of psychiatry as a medical discipline has itself begun to be suspect; what with the increasing use of elective courses in undergraduate curriculi in many universities, and also the abandoning of the requirement for postgraduates destined to take up psychiatry first to spend one year in a medical/ surgical type rotating internship.

The compilation of papers comprising this 'book' seems likely to be intended as some kind of redress to this situation. They are a selection of supposedly definitive papers from the field of 'medical psychiatry' previously published over the past decade or so. The papers are almost entirely drawn from American journals and tend to be neurological rather than biological in their orientation. They compare somewhat unfavourably with the selected reviews from the British journal Hospital Medicine recently collected and published by the Royal College of Psychiatry, but the purnose of which was seemingly educative rather than political. It is anyway hard to justify such a publication as this. Surely such articles are more aptly either briefly abstracted or else listed and recommended by title.
A Colour Atlas of Paediatrics (Wolfe Medical Atlases-13) By Martha DYnski-Klein. Pp. 416, illustrated, har cover. London: Wolfe Publishing Ltd, 1975. $£ 10.00$. This is the thirteenth in a series of colour atlases relating to various medical specialities. It is a welcome addition to thes paediatric literature which will supplement, rather thap compete with, existing texts. It contains over 600 illustrations most of which are in colour. They cover a wide range oD clinical problems with special emphasis on neonatal and developmental disorders. Each illustration has a brief explanatory note by the author. In addition the wide range of normal appearances and responses in the newborn period ares well represented. Interestingly, the section on special syn $\vec{P}$ dromes includes illustrations of infantile autism, diseases of the hair, and the battered child.

Few children's doctors will be able to resist the temptation to test their powers of recognition. Two minor criticisms ars the rather excessive use of eponyms in the text and somed variation in the colour quality of the figures.

Although the material is not claimed to be comprehensive ir it nevertheless must represent a collection acquired from $v$ many years of paediatric practice. The price is undoubtedls rather high for a book of this size, but this should nof detract from its appeal to doctors and medical student 8 involved with paediatric problems.

\section{Surgical Pathology}

By Sir Charles Illingworth and Bruce M. Dick. Pp? vii +363 , illustrated, hard cover. Edinburgh: Churchilf Livingstone, 1975. $£ 11.00$.

This well known text book first appeared in 1932 and immedi ately established itself as essential reading for young surgeons? presenting themselves for their higher examinations. We nowwelcome the 11 th edition produced by Sir Charles Illingwe th who is undoubtedly the doyen of British surgical teachers andp Emeritus Professor of Surgery in the University of Glasgefvo Sadly his co-author for many years, Mr Bruce Dick, dïed 8 years ago.

This new edition, like its predecessors, is written in clear $\frac{\partial}{\partial}$ concise English and compresses into a commendably shorf space a completely up-to-date account of Pathology for theD Surgeon. This includes not only traditional naked eye and microscopic pathology but also relevant aspects of bio $\overrightarrow{\vec{B}}$ chemistry, physiology, immunology and other branches of laboratory medicine important to the surgeon.

There are preliminary general chapters which deal with response to injury, wound healing and shock, immunity:wound infection and tumours. There follow chapters which deal with the specific systems and which include a shor section on gynaecological pathology. As well as a clearlyo written text, there are copious drawings, photographs and $\mathrm{X}$-rays of high quality. Numerous references are included for further reading, both to classical texts and more recene papers. This is a book which can be recommended with complete confidence to candidates working for the Fellow-0 ships of the surgical colleges but it will also be a usefuP revision for the practising surgeon and reference book for the interested student.

Speakers will include

$$
\text { 20-21 February 1976, Baltimore, Maryland }
$$

Wallace Fox,

Director, British Medical Research Council, Tubercolosis and Chest Diseases Unit, London.
D. A. Mitchison,

Professor of Bacteriology and Director of the Department of Bacteriology, Royal Postgraduate Medical School, London.

Send application or for further information:

Mr Sheldon Elman, Baltimore City Health Department, Division of Tuberculosis Control, 111 N. Calvert Street, C-232 Baltimore, Maryland 21202. 